JONES, THOMAS A., and CARLTON R. JOHNSON, Exxon Production Research Co., Houston, TX

\section{Geologic History of a Basin Depicted by Computer Mapping}

Reconstructions of detailed geologic histories of basins have become an increasingly important part of the exploration process. However, a history that includes numerous stratigraphic horizons and several periods of orogeny and erosion usually involves handling such a great volume of data that use of a computer becomes necessary. A complete depiction of the geological history of a basin must include the geometric relationships between the various horizons (onlap, offlap, truncation, etc), the depths and thicknesses of the formations, and the effects of orogeny and erosion throughout the basin.

Most computer mapping programs generate interpolated grids that are used for drawing contour maps. These grids and maps can show configurations of horizons at various stages of basin development, and can also show pre-erosional and pre-orogenic forms. The procedures are: (1) Interpret major geologic events. (2) Capture data at each selected control point (elevations of each mappable horizon and unconformity, estimates of loss in thickness due to erosion, estimate tectonic tilts and structures). (3) Construct grids (prepare data, construct grids of present stratigraphy, construct grids of pre-erosional forms). The resultant grids are used to depict present structure, paleostructure, map isopach units, and draw stratigraphic cross sections.

\section{KADRI, I. B., Pakistan Petroleum Ltd., Karachi, Pakistan}

Prospective Evaluation Techniques in Less Explored Basins of World

Prospect evaluation in some of the less explored basins, such as offshore China and several southeast Asian and south Asian basins, is hampered by lack of data. Exploration ventures in such areas are generally labeled high risk, resulting in short-term, usually abortive, investment. Examples from Pakistan and China are presented, showing that condemnation of large areas on the basis of analogies with highly explored basins is generally due to limited availability of data and not due to lack of petroleum potential. In less explored basin areas, a more imaginative and conceptual approach is required to assimilate and synthesize limited exploration data.

Generalization with respect to gravity distribution of crudes in the Potwar basin, northern Pakistan, is also misleading. Detailed investigations indicate that gravity differentiation is a result of biodegradation, or is related to the type of source material and time and depth of burial. Nonmarine sediments in Pakistan have not been fully evaluated for their petroleum potential, however, the fact that almost all the interior basins in China produce oil from nonmarine reservoirs derived from nonmarine sources indicates that nonmarine sediments in Pakistan deserve greater attention.

KALDI, JOHN, Saskatchewan Mineral Resources, Regina, Saskatchewan, Canada

Porosity Styles of the Midale Field in Williston Basin of Southeastern Saskatchewan

The Midale oil field, southeastern Saskatchewan, lies on the northeastern flank of the Williston basin. The reservoir is in limestones, dolomites, and evaporites (mainly anhydrite) of the Midale Beds (Mississippian), that were deposited during a predominantly regressive episode on a shallow shelf.
The Midale Beds are divided into a lower, middle, and upper zone. Many of the characteristic pore types in these zones, as observed in thin section and under SEM, can be related to both original depositional environment and postdepositional diagenetic modifications.

The dominant styles of porosity in the fine-grained argillaceous limestones of the lower zone are secondary intraparticle, moldic, or microvuggy. These fabrics result from the preferential dissolution of cement or very fine shell debris. A lack of pore interconnections precludes these sediments from being effective reservoir rocks.

The most significant pore type in the middle zone is secondary intercrystalline porosity within fine-grained dolomite. This fabric is the result of solution of calcite or aragonite from between rhombs after incomplete dolomitization. A crinoidal grainstone with pervasive early diagenetic syntaxial rim cement forms a tight trap in the middle zone.

The upper zone consists of fractured calcareous microcrystalline dolomite. The main pore type is a non-fabric selective system of oblique to vertical microfractures, which may be associated with regional uplift or local salt solution. The presence of dolomite rhombs on fracture surfaces indicates that dolomitization was relatively late, postdating fracturing. The microfractures in the upper zone counteract the porosityoccluding effects of stylolitization and secondary anhydritization.

\section{KATZ, BARRY J., Texaco Inc., Bellaire, TX}

Evidence for Migration Along Fractures Within a Fine-Grained Carbonate Rock

A detailed geochemical investigation was undertaken to characterize both the soluble (bitumen) and insoluble (kerogen) organic components of DSDP Site 535. This work reveals an organically rich carbonate section of Valanginian to Hauterivian age. This stratigraphic interval contains as much as $11 \%$ organic carbon. The kerogen component is dominated by material with elevated atomic $\mathrm{H} / \mathrm{C}$ ratios, and thus is oil-prone. However, the entire section is thermally immature and has not reached the principal stage of petroleum generation and expulsion. The bitumen component is dominated by nonhydrocarbons (asphaltenes and NSOs) typical of thermally immature sediments. Gas chromatograms of the saturate fraction are also characteristic of thermally immature sediments, revealing a bimodal distribution of components and an abundance of steranes and triterpanes.

Within this limestone section, numerous fractures are filled with a "tar-like" material. Preliminary chromatographic analyses suggest that the "tar-like" character of this material may be the result of post-migration alteration. Also within this interval, chromatographic evidence suggests the presence of thermally mature, unaltered hydrocarbons. Computer modeling of maturity indicates that these mature hydrocarbons seemingly have migrated several tens, if not hundreds, of kilometers updip. The uniformity of physical properties throughout the Cretaceous limestone sequence and the association of these hydrocarbons and "tars" with the fractured and brecciated horizons suggest that the migration occurred along the fracture system.

\section{KELLER, GERTA, U.S. Geol. Survey, Menlo Park, CA}

Miocene Paleo-Oceanography and Paleo-Productivity

Deep Sea hiatuses in pelagic sequences are largely determined by surface productivity and the rate of sediment removal by bottom currents and corrosiveness of deep waters with respect to calcite and silica. In regions of high biotic productivity, sedimen- 